\title{
HUBUNGAN ANTARA INTIMATE FRIENDSHIP DENGAN SELF-DISCLOSURE PADA MAHASISWA PENGGUNA WHATSAPP
}

\author{
Muhammad Nabil Rizal dan Gumi Langerya Rizal \\ Prodi Psikologi, Universitas Negeri Padang \\ e-mail: muhammadnabilrizal@gmail.com, gumi.langerya@gmail.com
}

\begin{abstract}
Abstrak
Penelitian ini bertujuan untuk mendeskripsikan self-disclosure dan intimate friendship serta untuk mengetahui hubungan antara intimate friendship dengan self-disclosure pada mahasiswa pengguna WhatsApp. Jenis penelitian yang digunakan adalah kuantitatif korelasional. Teknik sampling yang digunakan adalah teknik purposive sampling, dengan sampel 111 mahasiswa pengguna WhatsApp di Sumatera Barat. Analisis data menggunakan Analisis regresi linier berganda dan analisis tambahan menggunakan Independent sample T Test. Self-disclosure pada mahasiswa pengguna WhatsApp cenderung rendah dan intimate friendship pada mahasiswa cenderung tinggi. Berdasarkan analisis data, diperoleh hubungan antara intimate friendship dengan self-disclosure pada mahasiswa pengguna WhatsApp. Nilai $R$ Square penelitian ini sebesar 0.505 yang berarti dimensi intimate friendship mempengaruhi self-disclosure sebesar 50.5\%. Analisis tambahan menunjukkan tidak terdapat perbedaan self-disclosure dan intimate friendship ditinjau dari usia dan jenis kelamin.
\end{abstract}

Kata kunci: Intimate friendship, self-disclosure, pengguna WhatsApp

\section{RELATIONSHIP BETWEEN INTIMATE FRIENDSHIP WITH SELF-DISCLOSURE ON STUDENTS WHATSAPP USER}

\begin{abstract}
This study aims to describe self-disclosure and intimate friendship and to find out the relationship between intimate friendship and self-disclosure in WhatsApp students. This type of research is correlational quantitative. The sampling technique used was purposive sampling technique, with a sample of 111 students who used WhatsApp in West Sumatra. Data analysis using multiple linear regression analysis and additional analysis using the Independent sample T Test. Self-disclosure on WhatsApp students tends to be low and intimate friendship on students tends to be high. Based on data analysis, obtained a relationship between intimate friendship with self-disclosure on WhatsApp users. The $R$ Square value of this study is 0.505 which means that the dimension of intimate friendship affects self-disclosure by 50.5\%. Additional analysis shows there is no difference in self-disclosure and intimate friendship in terms of age and gender.
\end{abstract}

Keywords: Intimate friendship, self-disclosure, WhatsApp user

\section{Pendahuluan}

Aplikasi komunikasi lewat internet cukup banyak, seperti WhatsApp, Line dan lainnya. Salah satu teknologi komunikasi yang paling banyak digunakan masyarakat sekarang ini adalah WhatsApp. We Are Sosial (2019) melaporkan bahwa pengguna WhatsApp di Indonesia sekitar 83 \% dari pengguna internet yang ada dan merupakan aplikasi terbanyak digunakan dalam aplikasi instant messager. Pengguna terbanyak WhatsApp adalah mahasiswa dan para profesional dengan total 
pesan yang mereka kirim rata-rata mampu 33 pesan dan 3 files media dalam satu hari terlepas dari keperluan lainnya (Shahid, 2018).

Komunikasi messenger menurut Knop, dkk. (2016) perlu hadir dan membuat kasus untuk diri mereka sendiri untuk didengar dan membantu dalam hal membuka diri. Komunikasi messenger lebih mungkin digunakan banyak orang untuk mengungkapkan informasi tentang masalah pribadi dan minat mereka (Attrill, 2012). Keterbukaan seseorang mengenai dirinya kepada orang lain atau khalayak disebut dengan self-disclosure. Self-disclosure merupakan pesan apapun tentang diri sendiri yang dikomunikasikan pada orang lain (Wheeless \& Grotz, 1976). Selain itu, self-disclosure adalah suatu bentuk komunikasi saat seseorang menyampaikan informasi tentang dirinya yang biasanya disimpan (DeVito, 2011).

Pengguna WhatsApp biasanya memberikan informasi melalui status ataupun chatting, yang menunjukan kegiatan mereka, perasaan, pengalaman, identitas mereka, kedalam suatu bentuk status pesan, dalam bentuk foto, video, lokasi, dan fitur lainnya. Buntaran dan Helmi (2015) mengatakan bahwa individu cenderung lebih nyaman untuk self-disclosure melalui media online dibandingkan secara langsung. Seseorang secara sadar maupun tidak sadar sering kali mengekspresikan dirinya di WhatsApp, baik berupa kegiatan atau perasaannya saat itu. Sependapat dengan hal ini, menurut Robinson (2017) individu dihadapkan dengan peluang terus-menerus untuk membocorkan detail pribadi dan menciptakan peluang untuk penyalahgunaan informasi yang diungkapkan. Selain itu, WhatsApp juga tidak terlepas dari bahaya jejak digital dan penyadapan. Ini berkaitan aktivitas jaringan online yang mempengaruhi keamanan data pengguna WhatsApp itu sendiri (Anwar \& Riadi, 2017).

Walrave, Vanwesenbeeck, dan Heirman (2012) menyatakan kerentanan remaja terhadap pengaruh teman sebaya mendorong mereka untuk mengungkapkan lebih banyak, serta penerimaan teman sebaya dalam pergaulan juga akan berkontribusi pada self-disclosure pada remaja (Rahmawati \& Soeharto, 2014). Selain itu, menurut DeVito (2011) perasaan menyukai dan mitra dalam hubungan akan mempengaruhi self-disclosure seseorang. Ini mengingat berkaitan dengan rasa suka, keakraban dan tingkat kepercayaan seseorang terhadap orang lain. Seorang melakukan self-disclosure kepada orang yang ia rasa dekat dan dapat dipercaya. Salah satu hubungan tersebut adalah intimate friendship.

Intimate friendship menurut Sharabany (1994) adalah sebuah hubungan yang memungkinkan masing-masing individu untuk bergantung pada teman, memiliki kesamaan minat atau saling berbagi pengalaman, dan juga memiliki kualitas dalam self-disclosure yang membuat individu dapat saling terbuka membicarakan pemikiran dan perasaannya masing-masing. Selain itu, menurut DeSousa dan Cerqueira-Santos (2011) intimate friendship adalah suatu bentuk hubungan yang secara virtual semua orang mengalami dengan orang yang berbeda sepanjang hidup. Intimate friendship dapat dicirikan sebagai hubungan bilateral, mutual, dan intim.

Individu yang dekat dengan individu lainnya akan memungkinkan semakin tinggi self-disclosure kepada orang tersebut. Keterbukaan seseorang akan mendorong keterbukaan orang lain kepadanya. Berbeda dari hasil penelitian sebelumnya yang dilakukan Pohan dan Dalimunthe (2017), mendapatkan hasil korelasi negatif antara intimate friendship dengan self-disclosure pada mahasiswa Psikologi pengguna Facebook. Hal ini menunjukkan semakin rendah intimate friendship maka semakin tinggi self-disclosure seseorang ataupun sebaliknya. Dari beberapa uraian di atas, 
adanya perbedaan antara teori dengan penelitian sebelumnya sehingga peneliti tertarik untuk melakukan penelitian kembali mengenai hubungan dari intimate friendship dengan self-disclosure pada mahasiswa pengguna WhatsApp.

\section{Metode penelitian}

Penelitian ini menggunakan jenis penelitian kuantitatif korelasional, yaitu penelitian yang bertujuan untuk mengetahui ada atau tidaknya hubungan diantara dua atau beberapa variabel, dalam penelitian ini variabel yang diteliti yaitu intimate friendship dan self-disclosure.

Teknik sampling yang digunakan dalam penelitian ini adalah purposive sampling, teknik ini dilakukan karena peneliti memiliki kriteria tertentu (Sugiyono,2013) kriteria sampling diantaranya mahasiswa yang berusia 18-25 tahun, berkuliah di PTN/ PTS di Sumatera Barat serta aktif menggunakan WhatsApp.

\section{Subjek penelitian}

Subjek pada penelitian ini yaitu 111 mahasiswa sesuai dengan kriteria yang sudah ditetapkan peneliti yaitu mahasiswa yang berkuliah di Sumatera Barat, yang menggunakan WhatsApp. Penggunaan WhatsApp sendiri terdapat kriterianya yaitu menggunakan WhatsApp dengan rentang keaktifan $>5$ dan kegiatan yang dilakukan bukan untuk berkomunikasi saja, 111 mahasiswa tersebut berkuliah di PTN/ PTS yang tersebar di Sumatera Barat.

\section{Variabel dan instrumen penelitian}

Variabel dalam penelitian ini adalah intimate friendship dan self-disclosure. Skala yang digunakan untuk mengukur self-disclosure berdasarkan Leung (2002), dengan 5 pilihan jawaban yaitu (Sangat setuju, Setuju, Netral, Tidak setuju, Sangat tidak setuju). Aitem yang digunakan sebanyak 19 aitem. 19 aitem tersebut kemudian dilakukan uji coba dan mendapatkan hasil bahwa terdapat 4 aitem yang gugur dan 19 aitem yang valid dengan rentang nilai 0,333 hingga 0,628, setelah itu dilakukan kembali analisis faktor dan tidak ada aitem yang gugur. Skala yang digunakan untuk mengukur intimate friendship berdasarkan skala yang disusun oleh Sharabany (1994), dengan 5 pilihan jawaban yaitu (Sangat setuju, Setuju, Netral, Tidak setuju, Sangat tidak setuju). Aitem yang digunakan sebanyak 48 aitem. 48 aitem tersebut kemudian dilakukan uji coba dan mendapatkan hasil bahwa terdapat 6 aitem yang gugur dan 42 aitem yang valid dengan rentang nilai 0,301 hingga 0,690 , setelah itu dilakukan kembali analisis faktor yang mana terdapat pula 3 aitem lagi yang gugur dan tersisa 39 aitem karena nilai $p<0,50$.

Tabel 1. Uji validitas dan reliabilitas

\begin{tabular}{lccc}
\hline \multicolumn{1}{c}{ Alat ukur } & Jumlah aitem & Validitas & Reliabilitas \\
\hline Intimate friendship & 39 & $0,333-0,628$ & 0,917 \\
Self-disclosure & 15 & $0,301-0,690$ & 0,802 \\
\hline
\end{tabular}


Tabel 2. Analisis faktor intimate friendship dan self-disclosure

\begin{tabular}{clccc}
\hline \multicolumn{1}{c}{ Variabel } & \multicolumn{1}{c}{ Dimensi } & KMO & MSA & Loading factor \\
\hline Self-disclosure & Depth/ intimacy & 0,686 & $0,593-0,827$ & $0,557-0,879$ \\
& Honesty & 0,649 & $0,611-0,740$ & $0,734-0,855$ \\
& Amount & 0,500 & 0,500 & 0,881 \\
& Valence & 0,500 & 0,500 & 0,751 \\
& Intention & 0,500 & 0,500 & 0,782 \\
& Kejujuran dan spontanitas & 0,625 & $0,582-0,729$ & $0,559-0,900$ \\
& Kepekaan dan pengertian & 0,699 & $0,611-0,760$ & $0,612-0,778$ \\
& Kelekatan & 0,814 & $0,789-0,844$ & $0,563-0,830$ \\
& Eksklusifitas & 0,854 & $0,798-0,907$ & $0,612-0,842$ \\
& Memberi dan berbagi & 0,724 & $0,717-0,734$ & $0,685-0,716$ \\
& Penerimaan dan pengorbanan & 0,661 & $0,574-0,766$ & $0,608-0,837$ \\
& Kegiatan yang sama & 0,800 & $0,683-0,882$ & $0,675-0,856$ \\
& Kepercayaan dan kesetiaan & 0,753 & $0,710-0,765$ & $0,505-0,811$ \\
\hline
\end{tabular}

\section{Prosedur dan analisis data}

Tahapan pertama yang dilakukan dalam penelitian ini adalah persiapan, dimana peneliti mencari fenomena yang terkait dengan tema. Setelah menemukan fenomena, peneliti kemudian membuat rumusan masalah yang tepat. Selanjutnya peneliti juga mencari populasi, dan teknik sampling yang tepat, dan yang terakhir peneliti mencari alat ukur yang sesuai dengan variabel tersebut.

Tahapan kedua yaitu pelaksanaan penelitian, alat ukur yang sudah didapatkan kemudian dilakukan proffesional judgement oleh dua orang dosen Jurusan Psikologi Universitas Negeri Padang. Setelah mendapat persetujuan dari pihak dosen, selanjutnya dilakukan uji validitas dan reliabilitas menggunakan alpha dan analisis faktor dengan bantuan SPSS for windows version 25. Aitem yang sudah teruji validitas dan reliabilitasnya kemudian disusun kembali untuk kemudian dapat digunakan dalam penelitian.

Tahapan yang terakhir yaitu analisis data, dalam penelitian ini data yang telah didapatkan kemudian dilakukan skoring. Kemudian melakukan uji normalitas untuk melihat apakah data terdistribusi normal atau tidak, dilakukan uji linieritas untuk melihat hubungan linier atau tidak antara kedua variabel dan uji multikolinieritas. Selanjutnya melakukan uji Analisis regresi linier berganda dengan bantuan SPSS for window version 25 dan analisis tambahan menggunakan uji independent sample t test.

\section{Hasil penelitian}

Penelitian ini dilakukan dengan menyebarkan angket secara online. Penyebaran kuesioner secara online dilakukan melalui google form yang kemudian memperoleh subjek sebanyak 133 , namun 111 yang memenuhi kriteria penelitian. Berikut merupakan hasil dari nilai mean dan uji analisis regresi linier berganda serta uji beda yang ditinjau dari usia dan jenis kelamin berdasarkan penelitian yang dilakukan. 
Tabel 3. Nilai mean dan standar deviasi

\begin{tabular}{lllllllll}
\hline \multirow{2}{*}{ Variabel } & \multicolumn{4}{c}{ Skor Empirik } & \multicolumn{3}{c}{ Skor Hipotetik } \\
\cline { 2 - 9 } & Min & Max & Mean & $\begin{array}{l}\text { Std. } \\
\text { Deviation }\end{array}$ & Min & Max & Mean & $\begin{array}{l}\text { Std. } \\
\text { Deviation }\end{array}$ \\
\hline Self-disclosure & 27 & 67 & 48,84 & 8,779 & 19 & 95 & 57 & 12.67 \\
Intimate friendship & 122 & 178 & 150,37 & 11,184 & 39 & 195 & 117 & 26 \\
\hline
\end{tabular}

Berdasarkan dari hasil perhitungan pada tabel di atas, nilai mean empirik sebesar 48,44 , nilai ini lebih kecil dibandingkan dengan nilai mean hipotetiknya yakni sebesar 57 . Perbedaan ini menunjukkan bahwa self-disclosure pada mahasiswa pengguna WhatsApp cenderung rendah. Nilai mean empirik intimate friendship adalah 150.37, lebih tinggi dibandingkan nilai mean hipotetik yaitu 117. Perbedaan ini menunjukkan bahwa intimate friendship pada mahasiswa cendrung tinggi.

Tabel 4. Hasil uji analisis regresi linier berganda

\begin{tabular}{ccccccc}
\hline Model & $\mathbf{R}$ & $\begin{array}{c}\mathbf{R} \\
\text { Square }\end{array}$ & $\begin{array}{c}\text { Adjusted } \\
\text { R Square }\end{array}$ & $\begin{array}{c}\text { Std. Error of } \\
\text { the Estimate }\end{array}$ & $\mathbf{F}$ & Sig \\
\hline 1 & $0.710^{\mathrm{a}}$ & 0.505 & 0.466 & 6.416 & 12.996 & $.000^{\mathrm{b}}$ \\
\hline
\end{tabular}

Berdasarkan tabel di atas, didapatkan nilai F hitung sebesar 12.996 dan Sig 0.000. Jika nilai Sig yang diperoleh $(0.000)<0.05$, maka HA diterima. Sehingga dapat disimpulkan terdapat hubungan antara intimate friendship dengan self-disclosure. Selain itu dapat juga dilihat sumbangan efektif yang diberikan intimate friendship terhadap self-disclosure dapat dilihat dari nilai $R$ Square. Nilai $R$ Square yang diperoleh yaitu sebesar 0.505. Dari nilai ini dapat ditafsirkan bahwa dimensi intimate friendship memiliki kontribusi sebesar 50,5\% terhadap self-disclosure dan 49,5\% lainnya dipengaruhi oleh faktor-faktor lain selain intimate friendship.

Peneliti menguji ada atau tidak adanya perbedaan self-disclosure dan intimate friendship ditinjau dari usia dan jenis kelamin. Disini kelompok usia dibagi dua yaitu, remaja akhir dan dewasa awal, sedangkan jenis kelamin terdiri dari laki-laki dan perempuan.

Tabel 5. Hasil uji beda self-disclosure ditinjau dari usia dan jenis kelamin

\begin{tabular}{lccccc}
\hline \multicolumn{1}{c}{ Keterangan } & Variabel & F & Sig. & t & Sig. (2-tailed) \\
\hline Usia & Self-disclosure & .570 & .452 & -.162 & .872 \\
Jenis Kelamin & Self-disclosure & .444 & .507 & -.343 & .732
\end{tabular}

Berdasarkan tabel output di atas, diketahui nilai sig. (2-tailed) sebesar $0.872>0.05$ atau dilihat dari nilai $t$ hitung yaitu $0.162<\mathrm{t}$ tabel (1.981). Sehingga dapat disimpulkan tidak adanya perbedaan dari self-disclosure ditinjau dari usia. Pada tabel self-disclosure ditinjau dari jenis kelamin, diketahui nilai sig. (2-tailed) sebesar $0.732>0.05$ atau dilihat dari nilai t hitung yaitu $0.343<\mathrm{t}$ tabel (1.981). Sehingga dapat disimpulkan tidak adanya perbedaan dari self-disclosure ditinjau dari jenis kelamin. 
Tabel 6. Hasil uji beda intimate friendship ditinjau dari usia dan jenis kelamin

\begin{tabular}{lccccc}
\hline Keterangan & Variabel & F & Sig. & t & Sig. (2-tailed) \\
\hline Usia & Intimate friendship & 1.685 & .197 & -1.738 & .085 \\
Jenis Kelamin & Intimate friendship & 3.721 & .056 & -1.371 & .173 \\
\hline
\end{tabular}

Pada tabel intimate friendship ditinjau dari usia, diketahui nilai sig. (2-tailed) sebesar $0.085>$ 0.05 atau dilihat dari nilai $t$ hitung yaitu $1.738<\mathrm{t}$ tabel (1.981). Sehingga dapat disimpulkan tidak adanya perbedaan dari intimate friendship ditinjau dari usia. Pada tabel intimate friendship ditinjau dari jenis kelamin, diketahui nilai sig. (2-tailed) sebesar $0.173>0.05$ atau dilihat dari nilai t hitung yaitu $1.371<\mathrm{t}$ tabel (1.981). Sehingga dapat disimpulkan tidak adanya perbedaan dari intimate friendship ditinjau dari jenis kelamin.

\section{Pembahasan}

WhatsApp merupakan salah satu media yang penggunanya didominasi oleh mahasiswa. WhatsApp dapat dimanfaatkan sebagai salah satu media self-disclosure bagi mahasiswa. Self-disclosure dapat dilakukan melalui chatting, video call dan story untuk mengungkapkan informasi ataupun perasaan seseorang. Mahasiswa sendiri berada ditahap perkembangan remaja akhir (18-21 tahun) dan dewasa awal (22-24 tahun).

Berdasarkan hasil penelitian di atas, self-disclosure pada mahasiswa pengguna WhatsApp cenderung rendah. Banyak hal yang mungkin menyebabkan rendahnya self-disclosure. Menurut Chen, Pan dan Chai (2013), pengungkapan diri media online cenderung mendorong individu lebih selektif untuk mengungkapkan diri terutama pada lingkungan yang memiliki resiko privasi tinggi. Selain itu, menurut Ruppel dkk (2016) pengungkapan diri secara tatap muka lebih tinggi dibandingkan melalui media online. Pengungkapan diri secara tatap muka lebih dalam pengungkapannya dibandingkan melalui media online. Namun pengungkapan diri melalui media online lebih kaya dalam segi pengungkapan teks, video dan lainnya.

Intimate friendship pada mahasiswa berdasarkan hasil di atas, cenderung tinggi. Mahasiswa pada rentang usia 18-25 (mahasiswa S1), pada kisaran usia tersebut juga sedang aktif untuk menjalin hubungan. Di dalam perkuliahan, mahasiswa sering berkomunikasi, mengerjakan tugas kelompok dan bermain bersama. Ketika individu merasa saling cocok, maka hubungan pertemanan akan memasuki tahap selanjutnya dan semakin kuat bukan sebatas hubungan individu yang saling kenal atau membutuhkan.

Berdasarkan hasil di atas, intimate friendship memiliki hubungan positif dengan self-disclosure. Self-disclosure akan dilakukan kepada orang yang dianggap dekat oleh individu. Derlega (dalam Gainau, 2009) mengemukakan bahwa seseorang akan lebih terbuka kepada orang dekat, seperti suami/istri, keluarga, sahabat, teman dekat dan biasanya pada orang yang disukai daripada orang yang tidak disukai. Intimate friendship dicirikan sebagai hubungan yang bilateral dan intim sehingga memungkinkan masing-masing individu untuk saling berbagi pengalaman dan membicarakan pemikiran atau perasaannya masing-masing. Dengan demikian masing-masing individu akan saling 
mengungkapkan dirinya. Sehingga self-disclosure diantara individu tersebut dapat mempererat hubungan atau hubungan mereka menjadi dekat/ intim.

Pada penelitian ini sumbangan efektif yang diberikan intimate friendship terhadap self-disclosure dapat dilihat dari nilai $R$ Square. Nilai $R$ Square pada analisis di atas adalah 0.505 . Hasil skor ini diinterpretasikan bahwa dimensi intimate friendship hanya memberikan kontribusi sebesar $50.5 \%$ dan masih ada $49.5 \%$ faktor lainnya mempengaruhi self-disclosure.

Jika ditinjau dari pembagian usia, menunjukkan tidak ada perbedaan self-disclosure diantara remaja akhir dan dewasa awal pada pengguna WhatsApp ( $t=0.452<1.981)$. Hal ini didukung penelitian sebelumnya, Setyaningsih (2016) mengatakan tidak adanya perbedaan dalam self-disclosure diantara remaja dan orang dewasa. Menurut Christofides, Muise dan Desmarais (2012) mengatakan bahwa selama keinginan untuk populer tinggi maka memungkinkan tidak adanya perbedaan self-disclosure pada remaja dan dewasa. Selain itu, mahasiswa juga mengungkapkan privasi atau diri pribadinya secara ekstensif di media sosial. Livingstone (2008) mengatakan berdasarkan psikologi perkembangan, pemaknaan privasi akan berbeda antara remaja dan dewasa namun remaja dan dewasa sama-sama memiliki privasi yang akan mendorong atau tidak diri mereka untuk mengungkap diri pada media sosial.

Self-disclosure ditinjau berdasarkan jenis kelamin, didapatkan hasil tidak ada perbedaan self-disclosure antara laki-laki maupun perempuan pada pengguna WhatsApp. Hal ini sesuai dengan Fauzia, Maslihah dan Ihsan (2019), mengatakan bahwa tidak ada perbedaan self-disclosure pada laki-laki dan perempuan tetapi laki-laki dan perempuan lebih cenderung terbuka kepada perempuan daripada kepada laki-laki (Paluckaite \& Matulaitiene, 2012). Menurut Yu (2014) stereotip terhadap peran gender mungkin mempengaruhi keterbukaan individu (laki-laki maupun perempuan) kepada perempuan.

Intimate friendship jika ditinjau dari usia, menunjukkan tidak ada perbedaan skor intimate friendship antara remaja akhir dan dewasa awal terkhusus pada mahasiswa. Mahasiswa yang merupakan kelompok usia yang mengalami masa transisi dari remaja akhir ke dewasa awal. Pada dewasa awal perlu menentukan relasi atau hubungan, sehingga mahasiswa perlu menjalin hubungan dengan banyak orang serta harus dapat membina jaringan sosial yang baik untuk mencapai intimasi (Putri, 2019). Sedangkan pada masa remaja, intimate friendship berhubungan dengan kompetensi sosial (bersosialiasi) dan penyesuaian secara emosional oleh remaja (Kartika, 2014). Ketika memasuki masa remaja dan dewasa awal, teman dekat yang dimiliki individu tidak begitu banyak tetapi memiliki keintiman yang lebih erat dibandingkan hubungan lainnya.

Intimate friendship ditinjau dari jenis kelamin, menunjukkan tidak ada perbedaan skor intimate friendship antara mahasiswa laki-laki ataupun perempuan. Hal ini berbeda berdasarkan penelitian Riska dan Harmaini (2019) yang mengatakan adanya perbedaan intimate friendship ditinjau dari jenis kelamin. Anak perempuan lebih akrab dibandingkan anak laki-laki. Perbedaan tersebut disebabkan karena perempuan di usia yang lebih awal telah mengembangkan intimate friendship dibandingkan laki-laki (Sharabany, Eshel \& Hakim, 2008). 


\section{Kesimpulan}

Berdasarkan penelitian yang telah dilakukan, maka dapat disimpulkan sebagai berikut:

1. Intimate friendship memiliki hubungan positif dengan self-disclosure. Pada penelitian ini sumbangan efektif yang diberikan intimate friendship terhadap self-disclosure dapat dilihat dari nilai $R$ Square yaitu sebesar 0.505 . Hasil skor ini diinterpretasikan bahwa dimensi intimate friendship hanya memberikan kontribusi sebesar $50.5 \%$ dan masih ada $49.5 \%$ faktor lainnya mempengaruhi self-disclosure.

2. Hasil uji beda dari self-disclosure ditinjau dari usia, tidak menunjukkan adanya perbedaan diantara kelompok umur remaja akhir maupun dewasa awal. Selain itu hasil uji beda self-disclosure ditinjau dari jenis kelamin menunjukkan tidak adanya perbedaan self-disclosure diantara laki-laki maupun perempuan. Hasil uji beda dari intimate friendship ditinjau dari usia, tidak menunjukkan adanya perbedaan diantara remaja akhir maupun dewasa awal. Ditinjau dari jenis kelamin, tidak ada perbedaan intimate friendship diantara laki-laki maupun perempuan.

\section{Daftar Pustaka}

Anwar, N., \& Riadi, I. (2017). Analisis investigasi forensik WhatsApp Messenger smartphone terhadap WhatsApp berbasis Web. Jurnal Ilmu Teknik Elektro Komputer Dan Informatika, 3(1), 1-10. https://doi.org/10.26555/jiteki.v3i1.6643

Attrill, A. (2013). Sharing only parts of me: Selective categorical self-disclosure across internet arenas. International Journal of Internet Science, 7(1), 55-77.

Buntaran, F. A. A. \& Helmi, A. F. (2015). Peran kepercayaan interpersonal remaja yang kesepian dalam memoderasi pengungkapkan diri pada media jejaring sosial online. Gadjah Mada Journal of Psychology, 1(2), 106-119.

Chen, X., Pan, Y., \& Cai, S. (2013). User self-disclosure on SNSs : A privacy risk and social capital perspective. The International Conference on Electronic Business, 1-9.

Christofides, E., Muise, A., \& Desmarais, S. (2012). Hey mom, What's on your Facebook? Comparing Facebook disclosure and privacy in adolescents and adults. Social Psychological and Personality Science, 1-7. https://doi.org/10.1177/1948550611408619

DeSousa, D. A., \& Cerqueira-Santos, E. (2012). Intimate friendship relationships among young adults. Paidéia, 22 (53), 325-333.

DeVito, J. A. (2011). Komunikasi antarmanusia. Tangerang: Karisma Publishing Groups.

Fauzia, A. Z., Maslihah, S., \& Ihsan, H. (2019). Pengaruh tipe kepribadian terhadap self-disclosure pada dewasa awal pengguna media sosial Instagram di kota Bandung. Jurnal Psikologi Sains Dan Profesi, 3(3), 151-160. 
Gainau, M. (2009). Keterbukaan diri (self-disclosure) siswa dalam perspektif budaya dan implikasinya bagi konseling. Jurnal IImiah Widya Warta, 1-18.

Kartika, H. D. (2010). Hubungan antara sense of humor dan intimate friendship pada remaja. Psikologi Universitas Brawijaya, 1-11.

Knop, K., Oncü, J. S., Penzel, J., Abele, T. S., Brunner, T., Vorderer, P., \& Wessler, H. (2016). Offline time is quality time. Comparing within-group self-disclosure in mobile messaging applications and face-to-face interactions. Computers in Human Behavior, 55(1), 1076-1084. https://doi.org/10.1016/i.chb.2015.11.004

Leung, L. (2002). Loneliness, self-disclosure, and ICQ ("i seek you") use. Cyberpsychology \& Behavior, 5(3), 241-251.

Livingstone, S. (2008). Taking risky opportunities in youthful content creation: Teenagers use of social networking sites for intimacy, privacy and self-expression. New Media \& Society, 10(3), 393-411. https://doi.org/10.1177/1461444808089415

Paluckaitė, U., \& Matulaitienè, K. Ž. (2012). Gender differences in self-disclosure for the unknown person on the internet communication. Advanced Research in Scientific Areas, 961-966. https://doi.org/10.13140/2.1.5036.0328

Pohan, F. A \& Dalimunthe, H. A. (2017). Hubungan intimate friendship dengan self-disclosure pada mahasiswa Psikologi pengguna media sosial Facebook. Jurnal Diversita, 3(2), 15-24.

Putri, A. F. (2019). Pentingnya orang dewasa awal menyelesaikan tugas perkembangannya. SCHOULID: Indonesian Journal of School Counseling, 3(2), 35-40.

Rahmawati, U. M., \& Soeharto. (2014). Kontribusi penerimaan teman sebaya terhadap pengungkapan diri siswa kelas VIII SMP Negeri 1 Masaran tahun pelajaran 2013/2014. Jurnal Bimbingan Dan Konseling, 1-14.

Riska, N., \& Harmaini. (2019). Hubungan antara sense of humor dan intimate friendship. Psikoislamedia Jurnal Psikologi, 4(1), 36-47.

Robinson, S. C. (2017). Self-disclosure and managing privacy: implications for interpersonal and online communication for consumers and marketers. Journal of Internet Commers,.16 (4), 385-404.

Ruppel, E. K., Gross, C., Stoll, A., Peck, B. S., Allen, M., \& Kim, S. Y. (2016). Reflecting on connecting: Meta-analysis of differences between computer mediated and face to face self-disclosure. Journal of ComputerMediated Comunication. 1-17.

Setyaningsih, R. (2019). Memahami hubungan kebutuhan untuk populer dan keterbukaan diri (self-disclosure) pada pengguna Facebook: Sebuah tinjauan literatur. Proyeksi, 11(1), 93-104.

Shahid, S. (2018). Content analysis of Whatsapp conversations : an analytical study to evaluate the 
effectiveness of Whatsapp application in Karachi. International Journal of Media, Journalism and Mass Communications, 4(1), 14-26.

Sharabany, R. (1994). Intimate friendship scale: Conceptual underpinnings, psychometric properties and construct validity. Journal of Social and Personal Relationships, 11, 449-469.

Sharabany, R., Eshel, Y., \& Hakim, C. (2008). Boyfriend, girlfriend in a traditional society : Parenting styles and development of intimate friendships among Arabs in school. International Journal of Behavioral Development, 32(1), 66-75. https://doi.org/10.1177/0165025407084053

Sugiyono. 2013. Metode Penelitian Kuantitatif, Kualitatif, dan R \&D. Bandung: Alfabeta

Walrave, M., Vanwesenbeeck, I., \& Heirman, W. (2012). Connecting and protecting ? Comparing predictors of self-disclosure and privacy settings use between adolescents and adults. CyberPsychology: Journal of Psychology Research on Cyberspace, 6(1). https://doi.org/10.5817/CP2012-1-3

We are Social. (2019). Digital in 2019. Diperoleh dari https://wearesocial.com/global-digital-report-2019.

Wheeless, L. R., \& Grotz, J. (1976). Conceptualization and measurement of reported self-disclosure. Human Communication Research, 2(4), 338-346. doi:10.1111/j.1468-2958.1976.tb00494.x

Yu, T. (2014). Gender differences on self-disclosure in face-to-face versus E-mail communication. ICELAIC, 742-745. 